\title{
The potential role of vitamin D for prevention and treatment of tuberculosis and infectious diseases
}

\author{
Catia Dini ${ }^{(a)}$ and Antonio Bianchi ${ }^{(b)}$ \\ (a) Direzione Generale per la Cooperazione allo Sviluppo, Ministero degli Affari Esteri, Rome, Italy \\ (b) ASL di Bergamo, Bergamo, Italy
}

\begin{abstract}
Introduction.Vitamin D deficiency (VDD) is a common condition among several populations in the world. VDD is associated with higher incidence of immune system disorders and faster progression of some infectious diseases. Vitamin D is known to be of physiological importance, it is considered an essential micronutrient for the bone health and plays a beneficial role in the prevention and/or treatment of a number of chronic diseases. Vitamin D has a complex action on the immune system. Results. Evidence that vitamin D protects against tuberculosis has been supported by in vitro, epidemiological and some preliminary clinical studies. Vitamin D has a potential effect on HIV (human immunodeficiency virus) and plays a crucial role in the defence against respiratory infections. Conclusions. Vitamin D supplementation could be a low-cost, practical method to protect groups of people with high incidence of those diseases. Public health education should stress the need for adequate dietary intake of vitamin $\mathrm{D}$ in those vulnerable groups.
\end{abstract}

Key words: VDD, Vitamin D deficiency, tuberculosis, HIV, respiratory infections.

\begin{abstract}
Riassunto (Il ruolo potenziale della vitamina D nella prevenzione e terapia della tubercolosi e delle malattie infettive). Introduzione. La carenza di vitamina D è una condizione comune in numerosi gruppi di popolazione nel mondo. Essa risulta associata a un'elevata incidenza dei disturbi del sistema immunitario e a una più veloce progressione di alcune malattie infettive. Oltre ad essere un micronutriente essenziale per la salute dell'apparato scheletrico, la vitamina D riveste un ruolo importante nei processi fisiologici e nella prevenzione e/o terapia di numerose patologie croniche. Essa svolge un'azione complessa sul sistema immunitario. Risultati. La dimostrazione che la vitamina D protegge contro la tubercolosi è stata supportata da studi in vitro, epidemiologici e da alcuni dati clinici preliminari. La vitamina D ha un effetto potenziale sull'HIV (sindrome da immunodeficienza acquisita) e svolge un ruolo fondamentale nelle infezioni respiratorie. Conclusioni. La somministrazione di vitamina $\mathrm{D}$ può essere un metodo pratico, a basso costo per proteggere gruppi specifici di popolazione con elevata incidenza delle suddette malattie. L'educazione sanitaria pubblica dovrebbe mettere in risalto la necessità di una adeguata assunzione di vitamina $\mathrm{D}$ in tutti i gruppi vulnerabili.
\end{abstract}

Parole chiave: carenza di vitamina D, tubercolosi, HIV, infezioni respiratorie.

\section{INTRODUCTION}

In the pre-antibiotic era, the role of vitamin $\mathrm{D}$ in prevention of infectious diseases has been very important. The cod liver oil, one of the most important nutritional source of vitamin $D$, was used both for treatment of rickets and tuberculosis (TB). Moreover, research has stressed the important role of vitamin D for the immune system. Due to the polyvalent action of vitamin $\mathrm{D}$ for the human health, in recent times its deficit has been investigated and associated with a number of different diseases.

Micronutrients as potential adjunctive immunotherapy are a growing field of medical attention since scientific evidence of a specific antimycobacterial activity of vitamin D3 in macrophages has in- creased. HIV (human immunodeficiency virus) and TB co-epidemics represent a setback to global control of tuberculosis. Hypovitaminosis D has been identified as a main risk factor for the development of TB. Therefore, vitamin D supplementation may represent a new strategy for the TB prevention and for the shortening of TB treatment in the face of growing drug resistance.

\section{Vitamin D: an historical perspective}

The discovery of vitamin $\mathrm{D}$ began with the recognition of rickets as childhood bone disease by Francis Glisson in 1650 . The association between rickets and a lack of sunlight exposure was reported by Sniadecki in 1822 . By the mid-19th century, cod liver oil has 
been established as an effective treatment for rickets [1]. Mellanby emphasized the role of the vitamin D as the preventing agent of rickets in 1919 [2]; while the first demonstration of its anti-rachitic properties was given by Elmer McCollum in 1922 [3]. By the 1930s, the use of cod liver oil in the treatment and prevention of rickets became common place. The bridging of the knowledge that photosynthesized vitamin D and vitamin $\mathrm{D}$ in cod liver oil were similar was responsible for the eventual conquest of rickets. In the same way, the utilization of vitamin D for treatment of tuberculosis was common in the pre-antibiotic era [4]. In the mid-19th century, cod liver oil was reported by Williams to provide improvement to patients with pulmonary tuberculosis [5] and it was subsequently found to contain high quantities of vitamin D3. The isolation of vitamin D3 from cod liver oil in order to treat tuberculosis in the 1930s led to its widespread use in TB treatment and prevention, until the introduction of antibacterial chemotherapy in the 1950s.

\section{VITAMIN D: MECHANISM OF ACTION Vitamin D: endocrine metabolism}

Vitamin D is considered an essential micronutrient. It is well known for its important role, together with calcium, in bone mineralization. Vitamin D in human body is present in several forms: the most important are 1,25-hydroxyvitamin $\mathrm{D}$, the circulating form, and 1,25- dihydroxyvitamin $\mathrm{D}$, the active form. Vitamin D is produced in the skin through exposure to UV light (through the transformation of 7-dehydrocholesterol in vitamin D3 or cholecalciferol) or absorbed from few foods. Vitamin D can be ingested in the form of vitamin D3 or vitamin D2 (ergocalciferol). Vitamin D2 is derived from irradiation of the fungal steroid ergosterol. The vitamin $\mathrm{D}$ is processed by 25 -hydroxylase present in the liver to produce 1,25 -hydroxyvitamin D. Finally 25 hydroxyvitamin $\mathrm{D}$ is transformed by the enzyme 25hydroxyvitamin D-1-a-hydroxylase (CYP27B1) in 1,25-hydroxyvitamin $\mathrm{D}$, its active form. An important target organ for generation of 1,25-hydroxyvitamin $\mathrm{D}$ is the kidney, where the process is regulated by calcium metabolism signaling.

\section{Vitamin D role in the immune system and tuberculosis}

Vitamin D, in its active form 1,25-hydroxyvitamin $\mathrm{D}$, has a complex action on the immune system, by modulating and inhibiting its activity in different ways. In 2006, Liu and colleagues proved that Mycobacterium tubercolosis sensing by the Toll-like receptor 2/1 (TLR2/1) complex increases expression of vitamin D receptors (VDR) and CYP27B1 in monocytes [6]. The synthesis of 1,25-dihydroxyvitamin D promotes VDR-mediated transactivation of the antimicrobial peptide cathelicidin and killing of intracellular Mycobacterium tubercolosis.

Cathelicidins have a direct antimicrobial function. In addition to anti-bacterial effects including membrane disruption, they have antiviral effect in the inhibition of herpes simplex viruses, adenovirus and retrovirus [7]. A study showed that macrophages are most efficient in producing cathelicidin antimicrobial peptide LL-37 after infection with $M$. tuberculosis, suggesting that cathelicidin from macrophages may be an important participant in the innate immune response during early infection in humans [8]. Liu (2006) demonstrated that transcriptional regulation of cathelicidin can be mediated by activation of 1,25-dihydroxivitamin D. Stimulation of TLR receptors in macrophages by microbial products results in increased conversion from the inactive 25-hydroxyvitamin $\mathrm{D}$ to the active 1,25-hydroxyvitamin D. According to Adams and colleagues, a consequence of TLR activation is the production of defensin-2 and of cathelicidin: these two antimicrobical peptides are strongly up-regulated by 1,25-hydroxyvitamin D [9]. In fact, according to Liu (2006), serum from donors with insufficient levels of dihydrovitamin D supported a lower induction of cathelicidin in monocytes compared to serum of donors with sufficient vitamin $\mathrm{D}$ levels. A similar conclusion has been reported by the above study of Adams, using serum from patients with insufficient levels of vitamin D, before and after vitamin D supplementation. Those further experiments have confirmed earlier evidence: the $4 \mu \mathrm{g} / \mathrm{ml}$ concentrations of vitamin $\mathrm{D}$ metabolites have been able in a reproducible way to protect infected human macrophages and restrict mycobacterial growth in vitro [10].

The crucial role played by vitamin $\mathrm{D}$ in the immune response to $M$. tuberculosis consists, as well as the production of the LL-37, in promoting phagolysosome formation [11].

A research has documented that 1,25-dihydroxyvitamin D promotes autophagy in monocytes [12]. Autophagy and vitamin D3-mediated innate immunity have demonstrated to confer protection against infection with intracellular Mycobacterium tuberculosis. A study of Eun-Kyeong confirms the scientific findings that antimicrobial peptides play central roles in innate immunity to mycobacteria, including direct killing and indirect immune modulation. Of particular interest, human cathelicidin LL-37 has shown to be a key component linking vitamin D3-dependent immunity and autophagy [13]. The study wishes further researches into how cathelicidin regulates innate immune responses in order to facilitate the development of combinatorial treatments involving antimicrobial peptides, nutritional deficit correction and conventional chemotherapy. This could represent a breakthrough in therapies for $\mathrm{TB}$, especially for multidrug-resistant $\mathrm{TB}$, which shows resistance to conventional antibiotics.

On the other hand, vitamin D binds the vitamin $\mathrm{D}$ receptors on natural killer $\mathrm{T}$ (NKT) cells and CD8aa. Both cells have an important role in regulating citokine production and in protecting against the generation of autoimmunity [14]. Researches have demonstrated that 1,25 - dihydroxyvitamin $\mathrm{D}$ is a potent modulator of the T-cell phenotype: it inhibits the T-helper (Th) $1 \mathrm{~T}$ cells associated with cellular immune response while conversely enhancing humoral 
Th2 cells response $[15,16]$. A recent finding indicates that a balance between pro-(Th1) and anti (Th2) inflammatory responses is optimal for control of TB, thus suggesting that the role of 1,25-dihydroxyvitamin D3 may have a relevant importance [17].

\section{VITAMIN D DEFICIENCY IN THE WORLD An overview}

It is now widely recognized that vitamin $\mathrm{D}$ deficiency (VDD) is one of the most common conditions in the world. It has been estimated that upward of $50 \%$ of both children and adults living in the United States, Canada, Mexico, Europe, Asia, New Zealand, and Australia have vitamin D deficiency [18].

A recent national survey in the United States demonstrated that the prevalence of vitamin D insufficiency doubled in the last ten years: more than $90 \%$ of pigmented populations (Blacks, Hispanics, and Asians) suffer from vitamin D insufficiency, as well as nearly three fourths of the white population [19].

The reason why both Hispanics and Blacks are at much higher risk for VDD is mainly related to their skin pigmentation that gives them a natural sun protection factor, thereby reducing by $50 \%$ to $90 \%$ skin's efficiency in producing vitamin D3. When black American men and women were exposed to simulated sunlight, they were unable to raise their blood levels of vitamin D3, whereas white adults who received the same amount of simulated sunlight raised their blood levels of vitamin D3 by almost 50 fold [20]. High prevalence of hypovitaminosis D among black Americans has been found mainly in women [21].

A clinical research that investigated vitamin D metabolism showed that people from India residing in southern United States have reductions in serum vitamin $\mathrm{D}$ and $25(\mathrm{OH}) \mathrm{D}$ and are at risk of developing VDD, rickets and osteolmacia [22].

People in poor countries often have low vitamin $D$ levels. In addition, darkly pigmented skin reduces the amount of UV light available in the skin for production of vitamin D. A comparative study carried out in Ethiopia has demonstrated that both ordinary Ethiopians and full term pregnant Ethiopian women living in Addis Ababa have a significantly decreased vitamin D status compared with pregnant Norwegian women living in Oslo [23].

In the Indian sub-continent several studies assessed the vitamin D level in the population. A study conducted in Northern Pakistan found $89 \%$ of adult patients with low vitamin D level [24]. An investigation from India has drawn attention towards wide prevalence of VDD in all the country, in all age groups including newborns, children, pregnant women and adult males and females residing in rural and urban areas. In both areas, widely prevalent VDD is functionally relevant to skeletal health including osteomalacia and rickets [25]. In 2005 a very high prevalence of hypovitaminosis $\mathrm{D}$ was observed in a research carried out among pregnant women and their newborn in northern India [26]. An investigation in Mysore found that sixty-seven percent of women had vitamin D deficiency and that at ages 5 and 9.5 years, children born to vitamin D-deficient mothers had smaller arm-muscle area in comparison with children born to mothers without deficiency [27]. A parallel research in New Delhi assessed a very high prevalence of vitamin $\mathrm{D}$ deficiency in healthy term born infants at the age of 3 months and their mothers in winter as well as summer [28].

In the Middle East and other Arab countries, the hypovitaminosis $\mathrm{D}$ is very frequent in children and adults. A cross-sectional study observed high prevalence of VDD in apparently healthy children living in Jeddah [29]. For cultural and religious reasons, the dress style of women outdoors prevents exposure of skin to sunlight. A cross-sectional randomized study conducted in Saudi Arabia indicated that VDD among healthy Saudi women of 25-35 years was $30 \%$ and $55 \%$ in women of $\geq 50$ years [30]. In Iran high percentage of VDD was defined in a population study: in Teheran prevalence of severe, moderate and mild VDD was $9.5 \%, 57.6 \%$ and $14.2 \%$ respectively [31]. New lifestyles, with an increase in time spent in artificial environment (offices, houses, commercial centres), mainly in the hottest season, limit the physiological ability of human body to synthesize from precursor "active" form of vitamin $\mathrm{D}$.

The prevalence of vitamin D deficiency increased significantly with age. Although vitamin D levels may differ by latitude and skin pigmentation worldwide, there is growing evidence that living in sunlit areas may not provide adequate amounts of vitamin D, especially in postmenopausal women and old people. A study in Brazil assesses that although severe vitamin $\mathrm{D}$ deficiency leading to rickets or osteomalacia is rare in the country, there is accumulating evidence of the frequent occurrence of subclinical VDD, especially in elderly people [32].

\section{Hypovitaminosis $D$ and main diseases}

Much debate has taken place over the definition of vitamin $\mathrm{D}$ deficiency. Most agree that a $25(\mathrm{OH}) \mathrm{D}$ concentration $\leq 50 \mathrm{nmol} / \mathrm{L}$, or $20 \mathrm{ng} / \mathrm{mL}$, is an indication of vitamin $\mathrm{D}$ deficiency, whereas a $25(\mathrm{OH}) \mathrm{D}$ concentration of $51-74 \mathrm{nmol} / \mathrm{L}$, or $21-29 \mathrm{ng} / \mathrm{mL}$, is considered to indicate insufficiency; concentrations $>30 \mathrm{ng} / \mathrm{mL}$ are considered to be sufficient [33]. VDD is associated with various chronic diseases: osteopathy, myopathy, infections, inflammatory disease, hypertension, and diabetes mellitus [34], and auto-immune diseases (systemic lupus erythematosus and rheumathoid arthritis) [35] and is a risk factor for developing cardiovascular disease [36].

Rickets, although rare, is still diagnosed in the United States. Infants who are recent immigrants or adopted from orphanages abroad are at risk for rickets [37]. Vitamin D deficiency rickets is persistent in Canada, particularly among children who reside in the north and among infants with darker 
skin who are breastfed without appropriate vitamin D intake [38].

Rickets is among the most frequent childhood disease in many developing countries. In the Indian subcontinent and Middle East rickets is directly caused by VDD [39]. Moreover, a study in India suggests that rickets is common in malnourished children [40]. Inadequate exposure to sunlight appears to be the main factor responsible for the high incidence of the disease. In addition, malnutrition may contribute to the development of rickets [41].

The VDD is an important factor in the development of osteoporosis. An international epidemiological investigation of 18 countries at various latitudes conducted in 2004 and 2005 found a prevalence of vitamin D inadequacy among women with osteoporosis [42] and a study carried out in Italy assessed a high prevalence of osteoporosis in postmenopausal women due mainly to VDD [43].

\section{VITAMIN D DEFICIENCY AND TB}

TB patients frequently have lower vitamin D levels than the general population. Scientific research is studying the effect of vitamin D on the course of the TB disease. A recent study in Spain indicated that a high proportions of contacts of TB patients had low serum $25(\mathrm{OH}) \mathrm{D}$ levels and suggested that sufficient $25(\mathrm{OH}) \mathrm{D}$ levels protect against tuberculin skin test (TST) conversion, therefore supporting the hypothesis that deficient vitamin $\mathrm{D}$ status is a TB risk factor [44].

One of the major causes for globally VDD is a lack of sun-induced vitamin D synthesis. A survey in Germany among immigrant children and adolescents with a Turkish or Arab-Islamic origin found a high prevalence of vitamin D deficiency [45]. VDD has clearly re-emerged as a problem also in the UK, especially in children, mostly from Asian or Black ethnic minority groups [46]. The observation that migrants have lower serum vitamin $\mathrm{D}$ than do their healthy matched controls have led authors to conclude that the fall in vitamin D levels associated with migration from sunshine-rich to sunshine-poor areas is the cause for consequent reduction in cellular immunity that may allow a previously quiescent tuberculous focus to break down [47].

Martineau in 2011 observed that VDD was highly prevalent among black African adults living in Cape Town and is associated with susceptibility to active $\mathrm{TB}$ in both the absence and the presence of HIV infection, the association being stronger in HIV-infected people. Moreover, he pointed out that seasonal variations in vitamin $\mathrm{D}$ status and TB incidence among black Africans in Cape Town are causally related and suggested that all African immigrants should have their vitamin D levels checked, in order to restore the vitamin D deficiency [48].

A cross sectional study was conducted among pulmonary tuberculosis (PTB) patients in Mwanza, Tanzania to identify the predictors of their vitamin D status. The authors deduced that serum $25(\mathrm{OH}) \mathrm{D}$ is a valid measure of vitamin $\mathrm{D}$ status during the acute phase response and that the lower concentrations in PTB + patients may reflect increased utilization of vitamin D [49].

A study by Gibney confirms the strong association between VDD and Latent Tuberculosis Infection (LTBI) in African immigrants in Melbourne [50]. A further study, among sub-Saharan African immigrants attending the infectious diseases clinics in Melbourne, documents the frequency of latent or active TB infection and the relationship with vitamin D deficiency [51].

In the Indian sub-continent, TB has historically been a public health concern, due to a high prevalence and incidence in the general population. In a cohort follow-up study from Pakistan, low vitamin $\mathrm{D}$ levels were associated with progression to active TB disease in healthy household contacts. The findings suggested also the higher susceptibility of women to the infection, because of their low socioeconomic status, poor nutrition, traditional/cultural traits, and little exposure to sunlight [52]. In Southeast Asian countries, TB is also a major public health issue. A study among the Vietnamese population in Ho Chi Minh City suggests that low vitamin $\mathrm{D}$ status is an antecedent risk factor for TB [53].

A review of several observational studies (UK, Indonesia, Kenya, Thailand, Hong Kong, India) found that patients with TB have, on average, lower serum levels of vitamin D than healthy controls matched on sex, age, ethnicity, diet and geographical location. Worries about VDD and the risk of TB may therefore not be limited to Arab countries, Afro-Asian indigenous and migrant communities, as half of people in Europe aged more than 60 years are vitamin D deficient and concerns have been expressed in the UK about increasing malnutrition in the elderly [54].

\section{VITAMIN D DEFICIENCY AND HIV}

HIV represents a severe threat to the worldwide health, through population mobility. The VDD is particularly important in chronic illnesses, like HIV, both because the epidemiology of the disease coincides with the populations at higher risk of vitamin $\mathrm{D}$ deficiency and for the negative impact of protease inhibitors on vitamin D metabolism [55].

There is growing recognition of an association between VDD and the pathogenesis and course of HIV disease. According to a study, VDD was found frequent in HIV-infected persons of several countries of north, central, south Europe and Israel and was independently associated with a higher risk of mortality and HIV outcomes [56].

VDD has been demonstrated to be more frequent in HIV-positive patients than in healthy age and sex matched controls [57]. Insufficient levels of vitamin $\mathrm{D}$ may be one of several other risk factors contributing to the progression of HIV disease. Some crosssectional studies have indicated positive correlations between 1,25(OH)2D and CD4+ cell counts [58]. 
According to Spector, VDD is present in $25 \%$ to $75 \%$ of infected persons and has been associated with more rapid disease progression. In the meantime, infants born to HIV-infected women with vitamin D deficiency are at increased risk of infection and have decreased survival [59]. A study has indicated an association between low vitamin D levels and motherto-child transmission (MTCT) of HIV in developing countries. In a research in HIV-infected Tanzanian women, it was observed an increased risk of being HIV infected or of dying at birth for children born to women with a low vitamin $\mathrm{D}$ level at baseline. A low maternal vitamin D level was also associated with HIV transmission via breast-feeding and with higher infant mortality during follow-up [60].

In a further survey in the same cohort, low vitamin D levels at baseline were significantly associated with increased risk of HIV disease progression, severe anemia, and hypochromic microcytosis [61].

The above researches provide initial support for a potentially beneficial effect of adequate vitamin D status on HIV disease and related outcomes. Their results were consistent with one study which has found a correlation between higher vitamin $\mathrm{D}$ levels and increased survival times of HIV-infected patients [62].

Moreover HIV is correlated with the risk of tuberculosis co-infection. The TB is spreading quickly in developing countries, in sub-Saharan Africa and South Asia, and low-cost public health interventions for its prophylaxis are urgently needed. To restore the vitamin D level in the blood may prove to be an effective adjuvant treatment regimen for TB patients [63].

\section{VITAMIN D AND RESPIRATORY INFECTIONS}

Vitamin D has complex effects on pulmonary cell biology and immunity with impact on inflammation, host defence, wound healing, repair, and other processes. First of all the epitelial cells of lungs express high level of CYP27B1, supporting conversion of vitamin $\mathrm{D}$ in its active form. Those cells treated with supplement of vitamin D increase the production of cathelicidin [64]. Studies have established a possible link between vitamin $\mathrm{D}$ and respiratory infections by examining VDR polymorphisms. Single polymorphism in VDR has been associated with severe outcomes in respiratory syncytial virus and lower respiratory tract infections [65]. Findings provide preliminary evidence of associations of VDR polymorphisms with the risk of acute lower respiratory infections (ALRI), predominantly viral bronchiolitis, in young children, consistent with a potential role of vitamin $\mathrm{D}$ in the immune response to respiratory tract infection [66].

Epidemiological and experimental researches highlight that low levels of serum vitamin D is associated with impaired pulmonary function and it is potentially involved in a number of lung diseases [67]. Moreover, a case-control study in Ethiopia determined the role of VDD as predisposing factor for pneumonia in children aged under 5 years [68].
Vitamin D deficiency increases patients' vulnerability to viral respiratory infections [69] and it is also involved in the pathophisiology of chronic rhinitis and rhinosinusitis [70].

Vitamin D appears capable of inhibiting pulmonary inflammatory responses while enhancing innate defence mechanisms against respiratory pathogens [71]. A study suggested higher vitamin D concentrations as a protective "seasonal stimulus" against influenza and other aspects of respiratory health [72].

An Indian clinical trial on 27 children treated for six weeks with a supplement of vitamin D orally has shown reduction in respiratory infections [73], while a British study on 1740 elderly patients, treated with $800 \mathrm{IU}$ for two years, showed no significant reduction in respiratory infections [74]. The effect of vitamin D supplementation on incidence of respiratory infections seems relevant only when it is associated with a vitamin D deficiency, a relatively common situation in many developing countries. The findings have been confirmed by a Finnish research which found an association between $1,25(\mathrm{OH}) 2 \mathrm{D}$ concentration of less $16 \mathrm{ng} / \mathrm{ml}$ and an increase incidence of respiratory acute infections [75] and by a two-months study in Bangladesh which showed a significant correlation between lower levels of 25(OH)D $(11,7 \mathrm{ng} / \mathrm{ml}$ against $15,7 \mathrm{ng} / \mathrm{ml}$ of control group) and increased number of respiratory infections [76].

\section{VITAMIN D SUPPLEMENTATION}

Vitamin D has been attributed a significant role in host immune defence against $M$. tuberculosis as observational studies have found evidence of an association with VDD and active tuberculosis.

Clinical evidence using vitamin D in TB treatment was reported in several studies. The addition of vitamin D in the therapy of moderately advanced PTB had been proven to show a significant difference in sputum conversion compared with placebo. In a research carried out in Jakarta, the group treated with vitamin $\mathrm{D}$ had higher sputum conversion and radiological improvement (100\%) as compared to the placebo group (76.7\%) [77]. A black American woman with hypovitaminosis $\mathrm{D}$ and refractory drug-susceptible pulmonary TB was treated with antituberculous therapy and the correction of vitamin D deficiency. The patient demonstrated a significant radiographic improvement with negative sputum cultures at 13-month of total therapy [78].

In an Egyptian study vitamin D was administered to children with tuberculosis, showing that clinical improvement was more evident in patients taking vitamin $\mathrm{D}$ as compared to those who received treatment alone. The study concluded that vitamin D therapy may be very effective in addition to antituberculous drugs in the treatment of TB children [79].

Vitamin D has been suggested as prophylaxis in TB household contacts, being a low-cost intervention that is also easy to administer in resource-poor settings [80]. A research has demonstrated that a 
single oral dose of vitamin $\mathrm{D}$ enhanced tuberculosis contacts' antimycobacterial immunity in vitro. The finding that a single oral dose of $2.5 \mathrm{mg}$ vitamin D corrects profound vitamin D deficiency for at least 6 weeks, without causing hypercalcemia, underlines the potential use of this formulation as a safe, effective, and low-cost public health intervention [81].

The administration of a single oral dose of 50 000-150 000 IU of vitamin D early in winter may be a convenient way to maintain $25(\mathrm{OH}) \mathrm{D}$ levels within the desirable range in children [82]. Children affected by VDD are likely to have suboptimal bioavailability of vitamin $\mathrm{D}$, which might hamper their achievement of an adequate peak bone mass. Efforts to maintain an optimal supply of both vitamin D and calcium throughout the year seem warranted in order to facilitate bone accumulation and prevent osteoporosis later in life [83].

In veiled Arab women, vitamin D deficiency is the result of a combination of limitations in sunlight exposure and a low oral intake of vitamin D. Although exposure to sunlight is a key way to ensure enough levels of vitamin D in the body, however, addressing dietary intake of vitamin D to people who may avoid sunlight exposure for cultural believes seems a more successful way.

A research suggests that daily oral intake of vitamin D in sunlight deprived individuals should exceed $600 \mathrm{IU}$; probably it should be $1000 \mathrm{IU} /$ day to secure a normal level of 25-hydroxyvitamin D. This finding was confirmed in a cross-sectional study among randomly selected Moslem women of Arab origin living in Denmark. Although the daily oral intake of vitamin D among those veiled women was very high, (approximately $600 \mathrm{IU}$ ), they were still vitamin D-deficient [84].

An adequate supply of vitamin D may be important in HIV-infected individuals with their additional risk factors for osteopenia, neoplasias or cardiovascular disease [85]. Moreover vitamin D supplementation reduces the incidence of rheumatoid arthritis, insuline-dependent diabetes mellitus, multiple sclerosis $[86,87]$ and prevents the risk of osteoporotic fractures in older persons [88, 89].

The oral administration of vitamin D should consider an important fact: storage of vitamin D is difficult, particularly considering the risk of oxidative inactivation of the micronutrient. A key point for an effective supplementation should be the use of oral monodose, packed with commonly used nitrogen technology, to avoid any risk of oxidative stress. The

\section{References}

1. Thacher TD, Clarcke BL. Vitamin D insufficiency. Mayo Clin Proc 2011;86(1):50-60. http://dx.doi.org/10.4065/mcp.2010.0567

2. Mellanby E. An Experimental investigation on Rickets. Nutr Rev 2009;34(11):338-40.

http://dx.doi.org/10.1111/j.1753-4887.1976.tb05815.x cheap cost of vitamin D (60 USD/kg) makes it an affordable technology for developing countries.

\section{CONCLUSION}

The overlapping of HIV and TB epidemics creates an health care crisis. The potential ability of vitamin $\mathrm{D}$ to fight TB, a leading cause of death in HIV-infected patients, mainly in sub-Saharan Africa, could lead to decrease in mortality or slower the disease progression. Investing in TB control in poor settings can be a cost-effective approach.

The connection among vitamin $\mathrm{D}$, infections and immune function in the pediatric population indicates a possible role for vitamin D supplementation [90]. A study tested the association between vitamin D deficiency rickets and protein-energy malnutrition (PEM) in Ethiopian children and suggested that programmes targeting vitamin $\mathrm{D}$ deficiency rickets should give emphasis to children with PEM [91].

The relationship between rickets and maternal vitamin D deficiency has important implications for a comprehensive prevention strategy of vitamin $\mathrm{D}$ deficiency in women and children in the poorest settings of developing countries [92]. Moreover, the potential health consequences of VDD are very crucial in Africa and Asia where the infectious disease burden is high and malnutrition and famine are spreading in many populations, lowering their immune system [93]. Therefore programmes should be planned in order to provide vitamin D mainly to pregnant women and children.

In the western countries, more attention should be paid to the nutritional and vitamin $\mathrm{D}$ needs of older people and of all high risk groups (immigrants, HIVsubjects, TB patients) who are prone to hypovitaminosis $\mathrm{D}$.

Public health education should stress the need for adequate dietary intake of vitamin $\mathrm{D}$ in vulnerable groups of people all over the world.

The ideas expressed in this paper do not necessarily reflect any official view of the Italian Ministry of Foreign Affairs.

\section{Conflict of interest statement}

There are no potential conflicts of interest or any financial or personal relationships with other people or organizations that could inappropriately bias conduct and findings of this study.

Received on 14 May 2012

Accepted on 23 July 2012.
3. McCollum EV, Simmonds N, BeckerJE, Shipley PG. Studies on Experimental Rickets. XXI. An experimental demonstration of the existence of a vitamin which promotes calcium deposition. J Biol Chem 1922.

4. Ellman P, Anderson K. Calciferol in tuberculosis peritonitis with disseminated tuberculosis. BMJ 1948;1:394. http://dx.doi.org/10.1136/bmj.1.4547.394 
5. Williams CJB. Cod liver oil in phthisis. London. $J$ Med 1849; 1:1-18.

6. Liu PT, Stenger S, Li H, Wenzel I, Tan BH, Krutzik SR, Ochoa MT, Schauber J, Wu K, Meinken C, Kamen DL, Wagner M, Bals R, Steinmeyer A, Zügel U, Gallo RL, Eisenberg D, Hewison M, Hollis BW, Adams JS, Bloom BR, Modlin RL. Toll-like receptors triggering of a vitamin D mediated anti-microbical response. Science 2006; 311:1770-3. http://dx.doi.org/10.1126/science.1123933

7. Bals R, Wilson JM. Cathelicidins - a family of multifunctional antimicrobical peptides. Cell Mol Life Sci 2003;60: 711-20.

http://dx.doi.org/10.1007/s00018-003-2186-9

8. Rivas-Santiago B, Hernandez-Pando R, Carranza C, Juarez E, Contreras JL, Aguilar-Leon D, Torres M, Sada E. Expression of Cathelicidin LL-37 during mycobacterium tuberculosis infection in human alveolar macrophages, monocytes, neutrophils, and epithelial cells. Infect Immun 2008;76(3):935-41. http://dx.doi.org/10.1128/IAI.01218-07

9. Adams JS, Ren S, Liu PT, Chun RF, Lagishetty V, Gombart AF, Borregaard N, Modlin RL, Hewison M. Vitamin D directed rheostatic regulation of monocyte antibacterial responses. J Immunol 2009;182:4289-95. http://dx.doi.org/10.4049/jimmunol.0803736

10. Crowle AJ, Ross EJ. Comparative abilities of various metabolites of vitamin $\mathrm{D}$ to protect cultured human macrophages against tubercle bacilli. J Leukoc Biol 1990;47:545:50.

11. Chocano-Bedoya P, Ronnenberg AG. Vitamin D and tuberculosis. Nutr Res 2009;67(5):289-93. http://dx.doi.org/10.1111/j.1753-4887.2009.00195.x

12. Yuk JM, Shin DM, Lee HM, Yang CS, Jin HS, Kim KK, Lee ZW, Lee SH, Kim JM, Jo EK. Vitamin D induces autophagy in human monocytes/macrophages via cathelcidin. Cell Host Microbe 2009;6(3):231-43. http://dx.doi.org/10.1016/j.chom.2009.08.004

13. Eun-Kyeong J. Innate immunity to mycobacteria: vitamin D and autophagy. Cell Microb 2010;128(8):1026-35. http://dx.doi.org/10.1111/j.1462-5822.2010.01491.x

14. Cantorna MT. Why do T cells express the vitamin D receptor? Ann NY Acad Sci 2011;1217:77-82.

15. Overbergh L, Cecallome B, Waer M, Rutgeerts O, Valckx D, Casteels KM, Laureys J, Bouillon R, Mathieu C. 1alpha,25dihydroxyvitamin D3 induces an autoantigen-specific Thelper 1/T-helper 2 immune shift in NOD mice immunized with GAD65 (p524-543). Diabetes 2000;49(8):1301-7. http://dx.doi.org/10.2337/diabetes.49.8.1301

16. Boonstra A, Barrat FJ, Crain C, Heath VL, Savelkoul HF, O'Garra A. 1alpha,25-Dihydroxyvitamin d3 has a direct effect on naive CD4(+) T cells to enhance the development of Th2 cells. J Immunol 2001;167(4):4974-980

17. Lin PL, Flynn JL. Understanding latent tubercolosis: a moving target. J Immunol 2010;185(1):15-22. http://dx.doi.org/10.4049/jimmunol.0903856

18. Holick MF. Vitamin D deficiency. N Eng J Med 2007;357:26681. http://dx.doi.org/10.1056/NEJMra070553

19. Adams JS, Hewison M. Update in vitamin D. J Clin Endocrinol Metab 2010;95:471-8. http://dx.doi.org/10.1210/jc.2009-1773

20. Holick MF. Vitamin D: A D-Lightful solution health. $J$ Investig Med 2011;59:872-80. http://dx.doi.org/10.231/JIM.0b013e318214ea2d

21. Nesby-O'Dell S, Scanlon KS, Cogswell ME, Gillespie C, Hollis BW, Looker AC, Allen C, Doughertly C, Gunter EW, Bowman BA. Hypovitaminosis D prevalence and determinants among African American and white women of reproductive age: third National Health and Nutrition Examination Survey, 1988-1994. Am J Clin Nutr 2002;76:187-92.
22. Awumey EMK, Mitra DA, Hollis BW, Kumar R, Bell NH. Vitamin D Metabolism is altered in Asian Indians in the Southern United States: A Clinical Center Study. J Clin Endocrinol Metab 1998;169-73. http://dx.doi.org/10.1210/jc.83.1.169

23. Feleke Y, Abdulkadir J, Mshana R, Mekbib T, Brunvand L, Berg JP, Falch JA. Low levels of serum calcidiol in an African population compared to a North European population. Eur J Endrocrinol 1999;141:358-60. http://dx.doi.org/10.1530/eje.0.1410358

24. Mufti MA, Malhi UR, Zubair A, Badar I, Mufti M. Vitamin D levels in Adults in Northern Pakistan. RMJ 2012;37(1)

25. Goswami R, Mishra SK, Kochupillai N. Prevalence \& potential significance of vitamin D deficiency in Asian Indians. Indian J Med Res 2008;127:229-38.

26. Sachan A, Gupta R, Das V, Agarwal A, Awasthi PK, Bhatia V. High Prevalence of vitamin D deficiency among pregnant women and their newborns in northern India. Am J Clin Nutr 2005;81:1060-4.

27. Krishnaveni GV, Veena SR, Winder NR, Hill JC, Noonan K, Boucher BJ, Karat SC, Fall CHD. Maternal vitamin D status during pregnancy and body composition and cardiovascular risk markers in Indian children: the Mysore Parthenon Study. Am J Clin Nutr 2011;93:628-35.

http://dx.doi.org/10.3945/ajen.110.003921

28. Jain V, Gupta N, Kalaivani M, Jain A, Sinha A, Agarwal R. Vitamin D deficiency in healthy breastfed term infants at 3 months \& their mothers in India: Seasonal variation \& determinants. Indian. J Med Res 2011;133(3):267-3.

29. Mansour MMHK, Alhadidi KM. Vitamin D deficiency in children living in Jeddah, Saudi Arabia. Indian J Endocrinol Metab 2012;16(2):263-9. http://dx.doi.org/10.4103/2230-8210.93746

30. Al-Turki H, Sadat-Ali M, Al-Elq AH, Al-Mulhim FA, AlAli AK. 25-Hydoxyvitamin D levels among healthy Saudi Arabian women. Saudi Med J 2008;29(12):1765-8.

31. Hashemipour S, Larijani B, Adibi H, Javadi E, Sedaghat M, Pajouhi M, Soltani A, Shafaei AR, Hamidi Z, Khalili Fard AR, Hossein-Nezhad A, Booya F. Vitamin D deficiency and causative factors in the population of Tehran. BMC Public Health 2004:4:38. http://dx.doi.org/10.1186/1471-2458-4-38

32. Bandeira F, Griz L, Dreyer P, Eufrazino C, Bandeira C, Freese E. Vitamin D Deficiency: A Global Perspective. Arq Bras Endocrinol Metab 2006;640-6. http://dx.doi.org/10.1590/S0004-27302006000400009

33. Holick MF, Chen TC. Vitamin D deficiency: a worldwide problem with health consequences. Am J Clin Nutr 2008; 87(Suppl.):1080S-6S.

34. Thacher TD, Clarcke BL. Vitamin D Insufficiency. Mayo Clin Proc 2011;86(1):50-60. http://dx.doi.org/10.4065/mcp.2010.0567

35. Diniz Lopes Marques C; Tavares Dantas A; Sotero Fragoso T; Branco Pinto Duarte AL. The importance of vitamin D levels in autoimmune diseases. Bras J Rheumatol 2010;50(1):67-80.

36. Wang $\mathrm{T}$, Pencina MJ, Booth SL, Jacques PF, Ingelsson $\mathrm{E}$, Lanier K, Benjamin EJ, D'Agostino RB, Wolf M,Vasan RS. Vitamin deficiency and risk of cardiovascular disease. Circulation 2008:117:503-11. http://dx.doi.org/10.1161/CIRCULATIONAHA.107.706127

37. Rajakumar K. Vitamin D, cod-liver oil, sunlight, and rickets: A historical perspective. Pediatrics 2003;112;e132. http://dx.doi.org/10.1542/peds.112.2.e132

38. Ward LM, Gaboury I, Ladhani M, Zlotkin S. Vitamin Ddeficiency rickets among children in Canada. CMAJ 2007; 177(2):161-6. http://dx.doi.org/10.1503/cmaj.061377 
39. Pettifor JM. Vitamin D \&/OR calcium deficiency rickets in infants \& children: a global perspective. Indian J Med Res 2008; $127: 245-9$

40. Raghuramulu N, Reddy V. Serum 25-hydroxy-vitamin D levels in malnourished children with rickets. Arch Dis Child 1980;55:285-7.

http://dx.doi.org/10.1136/adc.55.4.285

41. Raghuramulu N, Reddy V. Studies on vitamin D metabolism in malnourished children. B J Nutr 1982;47:231-4. http://dx.doi.org/10.1079/BJN19820030

42. Lips P, Hosking D, Lippuner K, Norquist JM, Wehren L, Maalouf G, Ragi-Eis S, Chandler J. The prevalence of vitamin D inadequacy amongst women with osteoporosis: an international epidemiological investigation. J Intern Med 2006; 260:245-54

http://dx.doi.org/10.1111/j.1365-2796.2006.01685.x

43. Adami S, Giannini S, Bianchi G, Sinigaglia L, Di Munno O, Fiore CE, Minisola S, Rossini M. Vitamina D Status and response to treatment in postmenopausal osteoporosis. Osteoporos Int 2009;20(2):239-44.

44. Arnedo-Pena1 A, Juan-Cerdán JV, Romeu-Garcia1 A, Garcia-Ferrer D, Holguín-Gómez R, Iborra-Millet J, Herrero-Carot C, Sanchis Piñana MJ, Bellido-Blasco J, Ferrero-Vega JA, Safont Adsuaral L, Silvestre Silvestre E, Meseguer Ferrer N, Rodrigo Bartual V. Latent tuberculosis infection, tuberculin skin test and vitamin D status in contacts of tuberculosis patients: a cross-sectional and case-control study. Inf Dis 2011;11:349. http://dx.doi.org/10.1186/1471-2334-11-349

45. Hintzpeter B, Scheidt-Nave C, Mueller MJ, Schenk L, Mensink GBM. Higher prevalence of vitamin D deficiency is associated with immigrant background among children and adolescents in Germany. J Nutr 2007;1482-90.

46. Ladhani S, Srinivasan L, Buchanan C, Allgrove J. Presentation of vitamin D deficiency. Arch Dis Child 2004;89:781-4. http://dx.doi.org/10.1136/adc.2003.031385

47. Davies PDO, Brown RC, Woodhead SJ. Serum concentrations of vitamin D metabolites in untreated tuberculosis. Thorax 1985;40:187-90.

http://dx.doi.org/10.1136/thx.40.3.187

48. Martineau AR, Nhamoyebonde S, Oni T, Rangaka MX, Marais S, Bangani N, Tsekela R, Bashe L, de Azevedo V, Caldwell J, Venton TR, Wilkinson RJ. Reciprocal seasonal variation in vitamin $\mathrm{D}$ status and tuberculosis notifications in Cape Town, South Africa. Barry R. Bloom 2011. http://dx.doi.org/10.1073/pnas. 1111825108

49. Friis H, Range N, Pedersen ML, Mølgaard C, Changalucha J, Krarup H, Magnussen P, Søborg C, Andersen AB. Hypovitaminosis $\mathrm{D}$ is common among pulmonary tuberculosis patients in Tanzania but is not explained by the acute phase response. $J$ Nutr 2008;138:2474-80. http://dx.doi.org/10.3945/jn.108.094979

50. Gibney KB, MacGregor L, Leder K, Torresi J, Marshall C, Ebeling PR, Biggs B. Vitamin D deficiency is associated with tuberculosis and latent tuberculosis infection in immigrants from Sub-Saharan Africa. CID 2008;46:443-6. http://dx.doi.org/10.1086/525268

51. Gibney KB, Mihrshahi S, Torresi J, Marshall C, Leder K, Biggs B. The profile of health problems in African immigrants attending an infectious disease unit in Melbourne, Australia. Am J Trop Med Hyg 2009;80(5):805-11.

52. Talat N, Perry S, Parsonnet J, Dawood G, Hussain R. Vitamin D Deficiency and Tuberculosis Progression. Emerg Infec Dis 2010;16(5):853-5. http://dx.doi.org/10.3201/eid1605.091693

53. Ho-Pham LT, Nguyen ND, Nguyen TT, Nguyen DH, Bui PK, Nguyen VN, Nguyen TV. Association between vi- tamin D insufficiency and tuberculosis in a vietnamese population. BMC Infectious Diseases 2010;10:306. http://dx.doi.org/10.1186/1471-2334-10-306

54. Nnoaham KE, Clarke A. Low serum vitamin D levels and tuberculosis: a systematic review and meta-analysis. Int $J$ Epidemiol 2008;37:113-9.

http://dx.doi.org/10.1093/ije/dym247

55. Cozzolino M, Vidal M, Arcidiacono MV, Tebas $P$, Yarashesky KE, Dusso AS. HIV- protease inhibitors impair vitamin $\mathrm{D}$ bioactivation to 1,25 dihydroxyvitamin $\mathrm{D}$. AIDS 2003;17:513-20.

http://dx.doi.org/10.1097/00002030-200303070-00006

56. Viard J, Souberbielleb J, Kirkc O, Reekied J, Knysze B, Lossof M, Gatellg J, Pedersenh C, Bogneri JR, Lundgrenc JD, Mocroftd A. Vitamin D and clinical disease progression in HIV infection: results from the EuroSIDA study. AIDS 2011;25:1305-15. http://dx.doi.org/10.1097/QAD.0b013e328347f6f7

57. Vescini F. Vitamin D deficiency in HIV-positive patients. HAART and correlated pathologies. 2010;7:7-11.

58. Villamor E. A potential role for vitamin D on HIV infection? Nutr Rev 2006;64:226-33. http://dx.doi.org/10.1111/j.1753-4887.2006.tb00205.x

59. Spector SA. Vitamin D and HIV: letting the sun shine in. Top Antivir Med 2011;19(1):6-10.

60. Mehta S, Hunter DJ, Mugusi FM, Spiegelman D, Manji KM, Giovannucci EL, Hertzmark E, Msamanga GI, Fawzi WW. Perinatal outcomes, including mother-tochild transmission of HIV, and child mortality and their association with maternal vitamin D status in Tanzania. J Infect Dis 2009;200:1022-30. http://dx.doi.org/10.1086/605699

61. Mehta S, Giovannucci E, Mugusi FM, Spiegelman D, Aboud S, Hertzmark E, Msamanga GI, Hunter D, Fawzi WW. Vitamin D status of HIV-infected women and its association with HIV disease progression, Anemia, and Mortality. Plus one 2010;5:1-7. http://dx.doi.org/10.1371/journal.pone.0008770

62. Haug C, Mueller F, Aukrust P, Froland SS. Subnormal serum concentration of 1,25-vitamin $\mathrm{D}$ in human immunodeficiency virus infection: correlation with degree of immune deficiency and survival. J Infect Dis 1994;169:889-93. http://dx.doi.org/10.1093/infdis/169.4.889

63. Adams JS, Liu PT, Chun R, Modlin RL, Hewison M. Vitamin D in defense of the human immune response. Ann NY Acad Sci 2007;1117:94-105. http://dx.doi.org/10.1196/annals.1402.036

64. Hansdottir S, Monick MM, Hinde SL, Lovan N, Look DC, Hunninghake GW. Respiratory epithelial cells convert inactive vitamin $\mathrm{D}$ in its active form: potential effects on host defense. J Immunol 2008;11:965-74.

65. Beard JA, Bearden A, Striker R. Vitamin D and the antiviral state. J Clin Virol 2011;50:194-200. http://dx.doi.org/10.1016/j.jcv.2010.12.006

66. Roth DE, Jones AD, Prosser C, Robinson JL, Vohra S. Vitamin D receptor polymorphism and the risk of acute lower respiratory tract infection in early childhood. $J$ Infect Dis 2008;197:676-80. http://dx.doi.org/10.1086/527488

67. Herr C, Greulich T, Koczulla RA, Meyer S, Zakharkina T, Branscheidt M, Eschmann R, Bals R. The role of vitamin D in pulmonary disease: COPD, asthma, infection and cancer. Respir Res 2011;12:31. http://dx.doi.org/10.1186/1465-9921-12-31

68. Muhe L, Lulsegd S, Mason EK, Somones EAF. Case control study of the role of nutritional rickets in the risk of devel- 
oping pneumonia in Ethiopian children. The Lancet 1997; 349:1801-4 http://dx.doi.org/10.1016/S0140-6736(96)12098-5

69. Cannel J, Vieth R, Umhau JC, Holik MF, Grant WB, Madronich S, Garland CF, Giovannucci E. Review article: epidemic influenza and vitamin D. Epidemiol Infect 2006;134:129-40. http://dx.doi.org/10.1017/S0950268806007175

70. Abuzeid WM, Akbar NA, Zacharek MA. Vitamin D and Crhronic Rhinitis. Curr Opin Allergy Clin Immunol 2012;12(1): 13-7. http://dx.doi.org/10.1097/ACI.0b013e32834eccdb

71. Hughes DA, Norton R. Vitamin D and respiratory health. Clin Exp Immunol 2009;158:205. http://dx.doi.org/10.1111/j.1365-2249.2009.04001.x

72. Berry DJ, Hesketh K, Power C, Hypponen E. Vitamin D status has a linear association with seasonal infections and lung function in British adults. Brit J Nutr 2011;106:1433-40. http://dx.doi.org/10.1017/S0007114511001991

73. Rehman PK. Subclinical rickets and recurrent infections. $J$ Trop Pedatr 1995;40:58. http://dx.doi.org/10.1093/tropej/40.1.58

74. Avenel A, Cook JA, MacLennan GS, Macpherson CG. Vitamin D supplementation to prevent infections: a substudy of a randomised placebo-controlled trial in older people. Age Ageing 2007;36:574-7. http://dx.doi.org/10.1093/ageing/afm091

75. Laaksi I, Ruohola JP, Tuohimma P, Auvian A, Haatja R, Pihlajamäki H, Ylikomi T. An association of serum vitamin D concentrations $\leq 40 \mathrm{nmol} / \mathrm{l}$ with acute respiratory tract infection in young Finnish men. Am J Clin Nutr 2007;86:714-7.

76. Roth DE, Shah R, Black RE, Baqui AH. Vitamin D status and acute lower respiratory infections in early childhood in Sylhet, Bangladesh. Acta Paediatr 2010;99:389-93. http://dx.doi.org/10.1111/j.1651-2227.2009.01594.x

77. Nursyam EW, Amin Z, Rumende CM. The effect of vitamin $\mathrm{D}$ as supplementary treatment in patients with moderately advanced pulmonary tuberculous lesion. Acta Med Indones 2006;38:3-5.

78. Yamshchikov AV, Oladele A, Leonard MKJ, Blumberg HM, Ziegler TR, Tangpricha V. Vitamin D as Adjunctive Therapy in Refractory Pulmonary Tuberculosis: A Case Report. South Med $J$ 2009; 102(6):649-52. http://dx.doi.org/10.1097/SMJ.0b013e3181a5d37e

79. Morcos MM, Gabr AA, Samuel S, Kamel M, el Baz M, el Beshry M, Michail RR. Vitamin D administration to tuberculous children and its value. Boll Chim Farm 1998;137(5):157-64.

80. Wejse C, Olesen R, Rabna P, Kaestel P, Gustafson P, Aaby P, Andersen PL, Glerup H, Sodemann M. Serum 25-hydroxyvitamin $\mathrm{D}$ in a West African population of tuberculosis patients and unmatched healthy controls1-3. Am J Clin Nutr 2007;86:1376-83.

81. Martineau AR, Wilkinson RJ, Wilkinson KA, Newton SM, Kampmann B, Hall BM, Packe GE, Davidson RN, Sandra M,
Eldridge SM, Maunsell ZJ, Rainbow SJ, Berry JL, Griffiths CJ. A single dose of vitamin $\mathrm{D}$ enhances immunity to mycobacteria. Am J Respir Crit Care Med 2007;176:208-13. http://dx.doi.org/10.1164/rccm.200701-007OC

82. Oliveri B, Cassinelli H, Mautalen C, Ayala M. Vitamin D prophylaxis in children with a single dose of $150000 \mathrm{IU}$ of vitamin D. Eur J Clin Nutr 1996;50(12):807-10.

83. Docio S, Riancho JA, Pèrez A, Olmos JM, Amado JA, Gonzalez -Macias J. Seasonal Deficiency of Vitamin D in Children: A potential target for osteoporosis-preventing strategies? J Bone Miner Res 1998;13:544-8. http://dx.doi.org/10.1359/jbmr.1998.13.4.544

84. Glerup H, Mikkelsen K, Poulsen L, Hass E, Overbeck S, Thomsen J, Charles P, Eriksen EF. Commonly recommended daily intake of vitamin D is not sufficient if sunlight exposure is limited. JIM 2000;247:260-8. http://dx.doi.org/10.1046/j.1365-2796.2000.00595.x

85. Mueller NJ, Fux CA, Ledergerber B, Elzi L, Schmid P, Dang T, Magenta L. High prevalence of severe vitamin D deficiency in combined antiretroviral therapy-naive and successfully treated Swiss HIV patients. AIDS 2010;24:1127-34. http://dx.doi.org/10.1097/QAD.0b013e328337b161

86. Cantorna MT, Mahon BD. Mounting Evidence for Vitamin $\mathrm{D}$ as an environmental factor affecting autoimmune disease prevalence. Exp Biol Med 2004;229:1136-42.

87. Arnson Y, Amital H, Shoenfeld Y. Vitamin D and autoimmunity: new aetiological and therapeutic considerations. Ann Rheum Dis 2007;66:1137-42. http://dx.doi.org/10.1136/ard.2007.069831

88. Bishoff-Ferrari HA, Willet WC, Wong JB, Giovannucci E, Ditrich T, Dawson-Hughes B. Fracture prevention with vitamin D supplementation. JAMA 2005;293:2257-64. http://dx.doi.org/10.1001/jama.293.18.2257

89. Trivedi DP, Doll R, Khaw KT. Effect of four monthly oral vitamin D3 (cholecalciferol) supplementation on fractures and mortality in men and women living in the community: randomised double blind controlled trial. BMJ 2003;326:1-6. http://dx.doi.org/10.1136/bmj.326.7387.469

90. Walker VP, Modlin RL. The vitamin D connection to pediatric infections and immune function. Pediatr Res 2008;65:106R$13 R$. http://dx.doi.org/10.1203/PDR.0b013e31819dba91

91. Lulseged S, Fitwi G. Vitamin D deficiency rickets: socio-demographic and clinical risk factors in children seen at a referral hospital in Addis Ababa. East Afr Med J 1999;76(8):45761.

92. Dawodu A, Wagner CL. Mother-child vitamin D deficiency: an international perspective. Arch Dis Child 2007;92:737-40. http://dx.doi.org/10.1136/adc.2007.122689

93. Prentice A, Schoenmakers I, Jones KS, Jarjou LMA, Goldberg GR. Vitamin D deficiency and its health consequences in Africa. Clinic Rev Bone Miner Metab 2009;7:94-106. http://dx.doi.org/10.1007/s12018-009-9038-6 